\author{
Leszek Butowski \\ https://orcid.org/0000-0002-5885-7467 \\ Uniwersytet Łódzki \\ Wydział Nauk Geograficznych \\ Instytut Geografii Miast, Turyzmu i Geoinformacji \\ leszek.butowski@geo.uni.lodz.pl
}

\title{
GENEZA REFLEKSJI NAUKOWEJ NAD TURYSTYKĄ: PERSPEKTYWA EUROPEJSKA ${ }^{1}$
}

\begin{abstract}
Abstrakt: Celem artykułu jest uzupełnienie luki poznawczej w zakresie początków refleksji naukowej nad turystyka, widzianej przede wszystkim z perspektywy kontynentalnej Europy. Starano się to osiągnąć poprzez retrospektywną analizę rozwoju studiów nad turystyką w ujęciu chronologicznym oraz instytucjonalno-metodologicznym. Dzięki temu możliwe było wyróżnienie specyficznych okresów i podejść metodologicznych, na które złożyły się: 1) w układzie czasowym - okres prekursorski i okres studiów właściwych; 2) w układzie metodologicznym - studia jednodyscyplinarne i międzydyscyplinarne (interdyscyplinarne). Uzyskane wyniki umożliwiły sformułowanie wniosków ogólnych, również w formie tez, które mogą stanowić przedmiot krytycznej dyskusji. Dotyczy to zwłaszcza dominacji języka angielskiego oraz tradycji anglo-amerykańskiej w literaturze przedmiotu. Powoduje ona, że w świadomości badaczy zajmujących się tą tematyką wyłania się dalece niepełny (a przez to wypaczony) obraz dorobku światowych studiów nad turystyką. Składają się na niego bowiem także osiągnięcia mniejszych, choć mających czasami bardzo długą historię, „,szkół narodowych”, których dorobek pozostaje na arenie międzynarodowej prawie w ogóle nieznany. Autor ma nadzieję, że artykuł będzie stanowił zachętę do prowadzenia badań dotyczących początków studiów nad turystyką w poszczególnych krajach oraz do publikowania wyników tego typu analiz naukowych na arenie międzynarodowej, co z pewnością przyczyni się do uzupełnienia wiedzy z zakresu genezy refleksji naukowej nad tą dziedziną.
\end{abstract}

Słowa kluczowe: rozwój badań nad turystyką, historia i ewolucja, szkoła niemiecka, szkoła francuska, szkoła włoska, dominacja anglo-amerykańska, dorobek polski.

\section{WSTĘP}

Celem artykułu jest uzupełnienie luki poznawczej w zakresie początków refleksji naukowej nad turystyka, widzianej przede wszystkim z perspektywy kontynentalnej Europy. Problem ten wydaje się o tyle istotny, że w obrębie dominującej obecnie literatury anglojęzycznej panuje dość szeroko podzielany pogląd zakładający, że studia nad turystyką na szeroką skalę rozwinęły się dopiero po II wojnie światowej, a ich (trwający do dziś) rozkwit przypadł na lata 90. ubiegłego stulecia (Jafari, 1990, 2001). Dodatkowo badania z tego zakresu kojarzone są przede wszystkim z osiągnięciami szkoły i tradycji anglo-amerykańskiej, uzupełnionymi $\mathrm{w}$ ostatnich dekadach o dorobek badaczy z Australii i Nowej Zelandii, a niedawno także z Azji Południowo-Wschodniej (pozostających jednak pod wpływem tradycji anglojęzycznej). Zjawisko to, przejawiające się m.in. w przewadze języka angielskiego we współczesnych publikacjach stanowiących prezentacje wyników badań, zostało zidentyfikowane już jakiś czas temu i krytycznie opisane zarówno przez badaczy anglojęzycznych, jak i wywodzących się spoza tego obszaru językowego (np. Butowski, Kaczmarek, Kowalczyk-Anioł, Szafrańska, 2019; Chambers, Buzinde, 2015; Hall, 2004; Kozak, Kozak, 2016; McKercher, 2002; Wijesinghe, Mura, Bouchon, 2017). Przedstawione w dalszej części artykułu szczegółowe wyniki analizy retrospektywnej wskazują jednoznacznie, że początków badań nad tą dziedziną należy doszukiwać się poza obszarem języka angielskiego, w krajach kontynentalnej Europy. Przy czym studia te sięgają nawet drugiej połowy XIX w., o czym świadczą również prace z zakresu historii rozwoju poszczególnych dyscyplin łączących się z turystyką.

Natomiast próba zrekonstruowania syntetycznej genezy refleksji naukowej nad turystyką obejmującej wiele dyscyplin związanych z tą tematyką wydaje się zadaniem bardzo trudnym, o ile w ogóle możliwym. Świadczy o tym również fakt, że zadanie to było 
stosunkowo rzadko podejmowane w sposób kompleksowy, a do nielicznych autorów poruszających tę problematykę zaliczają się m.in. Vukonić (2012), Jafari i Xiao (2016) oraz Kozak i Kozak (2016). Oczywiście na samym początku należałoby postawić pytanie o celowość przeprowadzenia takiej retrospektywnej analizy. Nie chodzi bowiem tylko o to, aby w sposób mniej lub bardziej wyczerpujący wymienić wybranych autorów i przedstawić ich dorobek, przyporządkowując go ewentualnie do osiągnięć poszczególnych dyscyplin. Wydaje się raczej, że taka refleksja powinna prowadzić do sformułowania bardziej ogólnych wniosków. Wskazane jest, aby przełamywały one w jakimś stopniu utarte stereotypy dotyczące wkładu poszczególnych szkół i tradycji naukowych (również językowych) w rozwój badań nad turystyką. Jednocześnie wnioski z przeprowadzonej analizy mogą stanowić podstawę do podejmowania dalszych studiów, w których wyniku nakreślony zostanie pełniejszy obraz zjawisk turystycznych we współczesnym świecie, uwzględniający możliwie szerokie spektrum poglądów. Dzięki temu możliwe było poszerzenie naszej wiedzy o turystyce i jej różnych przejawach, a tym samym lepsze zrozumienie fenomenu tego zjawiska.

Mając świadomość, że realizacja tego zadania wychodzi znacznie poza ramy jednego artykułu, podjęto jednak próbę choćby częściowego zrekonstruowania genezy studiów nad turystyką. Przy czym pewne novum stanowi przyjęta pozycja metodologiczna sytuująca autora niniejszego tekstu poza układem jednodyscyplinarnym. Wydaje się bowiem, że takie właśnie podejście przeważało do tej pory przy podobnych analizach. Świadczy o tym wiele prac poświęconych historii badań nad turystyka, które były prowadzone głównie z perspektywy jednej dyscypliny (np. Jackowski, Bilska-Wodecka, Sołjan, Liro, 2015; Jafari, Xiao, 2016) lub co najwyżej ich grupy, np. w obrębie nauk społecznych (Dann, Liebman Parrinello, 2009). Natomiast być może jeszcze ważniejszym elementem sprawiającym, że uzyskane wyniki nie zawsze stanowią potwierdzenie dotychczasowych ustaleń (por. Kozak, Kozak, 2016), zwłaszcza w zakresie początków badań nad turystyka, jest świadome przyjęcie przez autora pozycji poza współczesnym głównym nurtem studiów nad tą dziedzina, przejawiającym się m.in. we wspomnianej wcześniej dominacji języka angielskiego. Jednym z jej negatywnych następstw jest bowiem ograniczenie do tego języka kwerend źródłowych, tak ważnych w analizach historycznych. Chcąc uniknąć tego niebezpieczeństwa, podjęto próbę zwrócenia się ku innym niż anglojęzyczne, pierwotnym źródłom literaturowym, przede wszystkim $\mathrm{w}$ obrębie języka francuskiego, niemieckiego i polskiego. Korzystano jednocześnie $\mathrm{z}$ wielu anglojęzycznych publikacji autorów nieanglojęzycznych, zwłaszcza kiedy dotyczyły one genezy studiów nad turystyką w ich krajach.
Oczywiście autor zdaje sobie sprawę, że przedstawiona analiza ma luki polegające na nieuwzględnieniu w niej przeglądu dorobku w zakresie badań nad tą dziedziną w dużej liczbie państw. Z jednej strony wydaje się, że jest to jednak przeszkoda obiektywna, która nie powinna uniemożliwić sformułowania głównych wniosków wynikających z badań. $Z$ drugiej zaś strony może ona stanowić zachętę do dalszych studiów weryfikacyjno-poznawczych dotyczących genezy badań nad turystyką, prowadzonych właśnie z perspektywy pominiętych szkół naukowych czy tradycji językowych.

\section{ANALIZA RETROSPEKTYWNA STUDIÓW NAD TURYSTYKA}

Mając na uwadze określony we wstępie artykułu cel badania, a także przyjęte założenia i ograniczenia, przeprowadzono retrospektywną analizę rozwoju studiów nad turystyką zarówno w ujęciu chronologicznym, jak i według rodzaju stosowanego podejścia instytucjonalno-metodologicznego. Dzięki temu możliwe było wyróżnienie wzajemnie powiązanych ze sobą okresów i sposobów prowadzenia badań, na które złożyły się: 1. W układzie metodologiczno-instytucjonalnym - dwa główne sposoby prowadzenia badań, obejmujące: - studia jednodyscyplinarne (jednoaspektowe);

- studia międzydyscyplinarne (wieloaspektowe).

2. W układzie czasowym - dwa podstawowe okresy studiów, określane tutaj jako:

- okres prekursorski (badania prowadzone w ujęciu jednodyscyplinarnym) - chronologicznie wcześniejszy;

- okres studiów właściwych (badania prowadzone zarówno w ujęciu jednodyscyplinarnym, jak i międzydyscyplinarnym) - chronologicznie późniejszy. Wspomnianą klasyfikację starano się przedstawić w sposób modelowy na rys. 1. Przy czym wyraźne czasowe oddzielenie zaproponowanych okresów: prekursorskiego i studiów właściwych nad turystyką (a w jego ramach badań jednodyscyplinarnych i międzydyscyplinarnych), okazało się niemożliwe, choćby ze względu na fakt, że wyróżnione fazy po części się pokrywają. Zaprezentowany podział ma więc charakter poglądowy, a zarysowane granice są umowne. To samo dotyczy rozróżnienia ze względu na stosowane podejścia metodologiczno-instytucjonalne. Badania jednodyscyplinarne bądź międzydyscyplinarne (nazywane także interdyscyplinarnymi) były bowiem często prowadzone w tym samym czasie, czy nawet przez tych samych badaczy w różnych okresach ich aktywności naukowej. Niemniej wydaje się, że wyróżnione okresy i ich charakterystyki metodologiczno-instytucjonalne wskazują na ogólne kierunki zmian, jakie w perspektywie długoterminowej można zaobserwować w odniesieniu do 
ewolucji studiów nad turystyką. Warto też zauważyć, że przedstawiona koncepcja rozwoju studiów nad turystyką stanowi po części spojrzenie alternatywne do propozycji Kozaka i Kozaka (2016), którzy przeprowadzili analizę ewolucji badań nad turystyką, wyróżniając $w$ niej trzy odmienne okresy przypadające z grubsza na lata:1) do 1960 r., 2) 1960-1990, 3) po 1990 r. Odróżnia się ona także od periodyzacji zaproponowanej przez $\mathrm{Vu}-$ konicia (2012), który wyodrębnił pięć stadiów rozwoju teorii turystycznej, obejmujących:1) okres poprzedzający rozwój turystyki (w jej współczesnym rozumieniu), tj. do połowy XIX w; 2) drugą połowę XIX stulecia - jako okres, w którym przygotowano pierwsze studia nad turystyką; 3) początek XX w. - do I wojny światowej; 4) okres międzywojenny; 5) okres po II wojnie światowej.

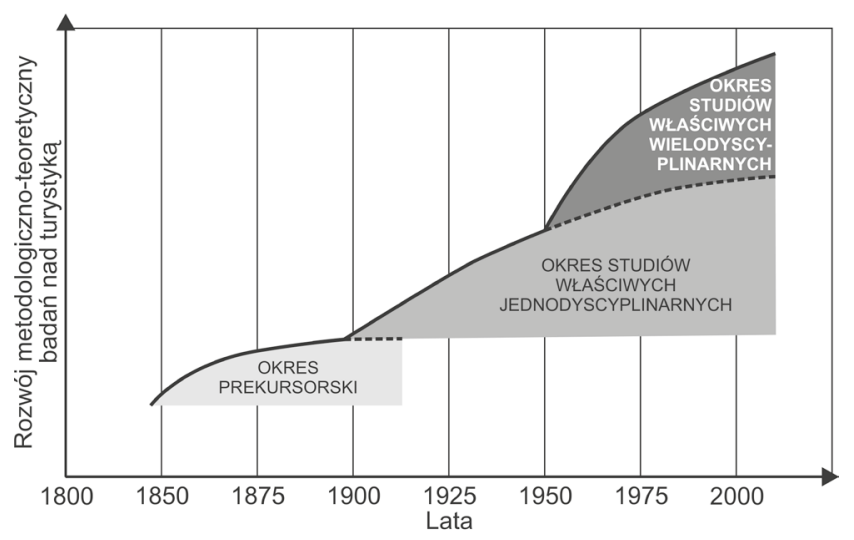

Rysunek 1. Rozwój metodologiczno-teoretyczny badań nad turystyką w funkcji czasu

Źródło: opracowanie własne

Biorąc pod uwagę zaprezentowane historyczne okresy rozwoju studiów nad turystyką w dalszej części artykułu przedstawiono ich bardziej szczegółową charakterystykę, uzasadniającą zaproponowany podział. Tak oto tzw. okres prekursorski, którego początki sięgają nawet połowy XIX w., obejmuje prace badaczy wywodzących się z różnych dyscyplin, którzy prowadząc $\mathrm{w}$ ich ramach studia, zajmowali się także problemami właściwymi turystyce - wtedy gdy nie stanowiła ona jeszcze autonomicznego przedmiotu badań (obszaru badawczego). Uczeni nie używali przy tym (co oczywiste) typowej dla tej dziedziny aparatury pojęciowej ani terminologii, ponieważ takowe były dopiero na etapie powstawania. Z kolei okres studiów właściwych nad turystyką to czas, kiedy dotyczące jej badania osiągnęły już taki stopień „dojrzałości”, że mogły stanowić autonomiczną dziedzinę refleksji naukowej, z własnym (na początku skromnym) instrumentarium, a nawet pewnym dorobkiem teoretycznym i metodologicznym. Trzeba przy tym zaznaczyć, że osiągnięcia te, zapożyczone najczęściej od innych bardziej zaawansowanych dyscyplin (głównie geografii, ekonomii i socjologii) i zaadaptowane do potrzeb badań nad turystyka, zostały scharakteryzowane przez wielu autorów, $\mathrm{w}$ tym m.in. przez Boguckiego i Woźniak (1997), Danna i Liebman Parrinello (2009), Hsu i Gartnera (2012), Jackowskiego, Bilską-Wodecką, Sołjan i Liro (2015), Jafariego i Xiao (2016) oraz Kowalczyka (2001).

Z kolei analiza początków refleksji naukowej and turystyką od strony metodologiczno-instytucjonalnej pozwoliła wyróżnić dwa rodzaje do pewnego stopnia przeciwstawnych podejść badawczych, na które złożyły się studia jednodyscyplinarne oraz międzydyscyplinarne. Przy czym te pierwsze rozumiane są tutaj jako badania prowadzone z perspektywy danej dyscypliny (jednoaspektowo), bez konieczności interdyscyplinarnej syntezy uzyskanych w ten sposób wyników. Z kolei w przypadku studiów międzydyscyplinarnych czynnikiem wyróżniającym jest próba wieloaspektowego podejścia do badanego problemu z położeniem akcentu na syntetyczną interpretację uzyskanych wyników badań przeprowadzonych $w$ ramach wielu dyscyplin. Warto przy tym zauważyć, że o ile pierwszy, prekursorski etap badań nad turystyką charakteryzował się podejściem jednodyscyplinarnym (ekonomia i geografia jako główne dyscypliny, w których ramach były prowadzone studia nad turystyką), to w okresie studiów właściwych (aż do dziś) stosowane jest wciąż zarówno podejście jednodyscyplinarne, jak i interdyscyplinarne. Należy jednak zaznaczyć, że $\mathrm{w}$ ramach podejścia jednodyscyplinarnego w obrębie niektórych dyscyplin ukształtowały się specyficzne subdyscypliny związane z problematyką turystyki ${ }^{2}$, jak np. geografia turyzmu, socjologia turystyki, antropologia turystyki, ekonomika turystyki itp. (por. Kozak, Kozak, 2016). Wydaje się jednak, że często pozostają one na marginesie głównego nurtu zainteresowań badawczych związanych z dyscyplinami, z których się wywodzą (por. Dann, Liebman Parrinello, 2009). Z kolei podejście międzydyscyplinarne, sugerowane m.in. przez Tribe'a (1997, 2006) jako najbardziej obiecujące, mimo że uważane obecnie za dające lepsze wyniki, wydaje się znacznie trudniejsze pod względem metodologii i organizacji badań. Tematyka ta podejmowana była zresztą przez wielu autorów, w tym m.in. przez Darbellaya i Stocka (2012), Leipera (1990), Smitha (1998), Tribe'a i Liburd (2016). Kozak i Kozak (2016) uważają np., że na rozwój podejścia interdyscyplinarnego wpływ miało podjęcie problematyki turystycznej przez pierwsze pokolenie badaczy, którzy uzyskali swoje stopnie naukowe w obrębie tej dziedziny, w przeciwieństwie do ich poprzedników wykształconych na ekonomistów, geografów czy socjologów. W literaturze, co warto zauważyć, spotykane są liczne modyfikacje i rozwinięcia podejścia interdyscyplinarnego, w zależności od stopnia syntetyzacji wyników badań, określane takimi terminami, jak: studia multidyscyplinarne, krossdyscyplinarne, transdyscyplinarne, a nawet postdyscyplinarne ${ }^{3}$ (Echtner, Jamal, 1997; Pearce, Butler, 1993; Rátz, 2014; Smith, 1998; Tribe, Xiao, 2011). 
Za względu na fakt, że okres prekursorski oraz pierwsza część okresu studiów właściwych nad turystyką (trwająca umownie do II wojny światowej) są najsłabiej poznane, to właśnie one będą stanowiły przedmiot analizy historycznej zawartej w niniejszym artykule ${ }^{4}$. Przy czym autor skoncentruje się przede wszystkim na wybranych krajach kontynentu europejskiego, głównie z uwagi na fakt, że właśnie w Europie (ale raczej poza obszarem języka angielskiego) należy się doszukiwać początków refleksji naukowej nad turystyka, co zdają się potwierdzać także badacze spoza tego kontynentu lub reprezentujący anglosaską tradycję studiów nad omawianą dziedziną (Dann, Liebman Parrinello, 2009; Jafari, Xiao, 2016; Vukonić, 2012). Twierdzenie to można zresztą potraktować jako hipotezę wymagającą sprawdzenia, zwłaszcza w odniesieniu do dorobku północnoamerykańskiego, w którego obrębie powstawały także prace poruszające problematykę turystyczną (Brown, 1935; Carlson, 1938; Joerg, 1935; Jones, 1933; McMurry, 1930; Meinecke, 1929). Wydaje się jednak, że miały one dość rozproszony charakter wynikający prawdopodobnie z indywidualnych zainteresowań naukowych poszczególnych badaczy.

\section{OKRES PREKURSORSKI}

Wydaje się, że dla okresu prekursorskiego (a zwłaszcza jego początków) szczególnie charakterystyczne były szeroko rozumiane badania ekonomiczne i geograficzne, z uwzględnieniem ich specyfiki uzależnionej od lokalnych uwarunkowań gospodarczych, politycznych czy historycznych. Dlatego w poszczególnych krajach lub regionach kładziono nacisk na różne aspekty takich studiów. Na przykład w Polsce (niemającej w tym okresie swojej państwowości) w początkowym okresie dominowały badania geograficzne o charakterze etnograficzno-kulturowym, często z eksponowaniem w nich wątków patriotycznych. Z kolei w Niemczech, Szwajcarii, Austrii, Francji i Włoszech dotyczyły one raczej wpływu na miejscową gospodarkę, osadnictwo, czy też kwestie środowiskowe, zwłaszcza w regionach alpejskich i nadmorskich, a także w miastach historycznych, odwiedzanych przez turystów. Również w okresie prekursorskim, ale nieco później, zaczęły się dynamicznie rozwijać, głównie na potrzeby lokalnych gospodarek turystycznych, badania aplikacyjne o charakterze stricte ekonomicznym. W literaturze polskiej charakterystykę pierwszego okresu studiów nad turystyka, przede wszystkim w zakresie nauk geograficznych, w nieco mniejszym stopniu zaś w odniesieniu do badań ekonomicznych i społecznych, przedstawili Warszyńska i Jackowski (1978), Kowalczyk (2001), Jackowski i Sołjan (2011), a także Jackowski, Sołjan, Bilska-Wodecka i Liro $(2015,2016)$. Przeanalizowali oni m.in. dorobek badaczy z przodujących pod tym względem szkół (niemieckojęzycznej i francuskiej). Próbując wyjaśnić, skąd wzięło się zainteresowanie geografów - jako pierwszych w środowisku naukowym ${ }^{5}$ - aktywnością turystyczna, Jackowski, Bilska-Wodecka, Sołjan i Liro (2015) sformułowali tezę, że zbiegło się ono w czasie ze zwróceniem się geografów ku zagadnieniom związanym z funkcjonowaniem człowieka w środowisku przyrodniczym, w co doskonale wpisywała się problematyka zwiększonej mobilności ludzi, w tym również mającej charakter turystyczny.

Wśród najwybitniejszych przedstawicieli nauk geograficznych z okresu prekursorskiego, funkcjonujących w obszarze języka niemieckiego, których dorobek stanowił podwaliny pod późniejsze studia właściwe nad turystyką (w tym również ekonomiczne), należałoby wymienić - za Jackowskim, Bilską-Wodecką, Sołjan i Liro (2015) - przede wszystkim: A. von Humboldta (1769-1859) - przyrodnika, dostrzegającego związki między środowiskiem a działalnością człowieka; K. Rittera (1779-1859) - regionalistę, uważanego (obok Humboldta) za jednego z twórców nowożytnej geografii; J.G. Kohla (1808-1878) - podróżnika, geografa i historyka; F. Ratzla (1844-1904), uznawanego za jednego z założycieli antropogeografii; a także jego ucznia A. Hettnera (1859-1941) - wybitnego teoretyka geografii; oraz K. Hasserta (1868-1947) - antropogeografa, specjalizującego się m.in. w geografii transportu. Wszyscy wymienieni naukowcy poruszali w mniejszym lub większym stopniu zagadnienia związane z turystyką (choć żaden z nich nie uważał się za jej badacza), czy to w ujęciu etnograficzno-krajoznawczym (np. Ratzel, 1882), czy też z zakresu geografii osadnictwa - w tym miejscowości turystycznych (m.in. Hassert, 1908; Hettner, 1927; Kohl, 1841), a niekiedy także w aspekcie ekonomicznym.

Z kolei w obrębie języka francuskiego na pierwszym miejscu należałoby wskazać P. Vidala de la Blache'a (1845-1918), który poprzez humanistyczne i zarazem regionalne ujęcie tematu $\mathrm{w}$ badaniach geograficznych wyznaczał bardzo dobre ramy metodologiczne, również dla studiów nad turystyką. Według Jackowskiego, Bilskiej-Wodeckiej, Sołjan i Liro (2015), to Vidalowi de la Blache'owi, wraz z innym geografem francuskim P. Lasserre'em, przypisuje się wprowadzenie terminu industrie touristique 6 - w odniesieniu do rozwoju miasta Lourdes, w związku z rozwijającym się tam ruchem pielgrzymkowym (Lasserre, 1930). We Francji w pierwszych dekadach XX w. podstawę instytucjonalną studiów geograficznych nad turystyką (ograniczoną jednak głównie do obszarów górskich Alp i pobliskiego Lazurowego Wybrzeża wraz z Korsyką) stanowiły utworzony w Grenoble w 1907 r. Instytut Geografii Alpejskiej (Institut de géographie alpine) oraz ukazujące się od 1913 r. czasopismo „Revue de Géographie Alpine". Ich założycielem był wybitny geograf R. Blanchard (1877-1965), który interesował się również 
zagadnieniami z zakresu turystyki. Badacz poświęcił im wiele publikacji wyprzedzających niejako okres studiów właściwych nad turystyką (Blanchard, 1911, 1914, 1919). W okresie do wybuchu I wojny światowej zaczęły się ukazywać także wyspecjalizowane przewodniki i czasopisma dla osób uprawiających pewne specyficzne formy turystyki - np. Le tourisme en automobile Auschera (1904) - w których publikowano również artykuły o charakterze naukowym.

Wybór dorobku badaczy niemiecko- i francuskojęzycznych do zilustrowania osiągnięć okresu prekursorskiego w studiach nad turystyką nie był przypadkowy. W zasadzie badacze są zgodni co do twierdzenia, że to właśnie $w$ tych krajach zostały one zapoczątkowane jeszcze w XIX w. Można jednak przypuszczać, że studia takie były prowadzone także $\mathrm{w}$ kilku innych państwach (o czym świadczy chociażby przykład Polski), wśród których na pierwszym miejscu należałoby wymienić Włochy (Avancini, 1925; Bodio, 1899; Stringer, 1912). Spode (2009) twierdzi wręcz, że Włochy (a nie Francja) były w pierwszym okresie, obok krajów niemieckojęzycznych, najważniejszym ośrodkiem badań nad turystyka.

\section{OKRES STUDIÓW WŁAŚCIWYCH}

Przechodząc do omówienia okresu studiów właściwych nad turystyka, trzeba podkreślić, że w sposób naturalny zaczęły się one również rozwijać w krajach niemieckojęzycznych. Pierwsze publikacje, w których podjęto tę tematykę, głównie z perspektywy ekonomicznej i geograficznej ${ }^{7}$, a także poświęcone problematyce hotelarskiej, czy też zagadnieniom związanym z promocją turystyki, pojawiły się tam bowiem już na początku XX w., a niektóre nawet wcześniej. Należały do nich m.in. prace ekonomiczne Guyera-Freulera (1874, 1884, 1895, 1905), Angerera (1881a, 1881b), Stradnera $(1890,1905)$, Brougiera $^{8}$ (1902), Justa (1907), Schullerna-Schrattenhofena9 (1911), Zollingera (1916), Glücksmanna (1917, 1935), Sputza (1919), Morgenrotha (1927), Bormanna (1931), Kriegera (1933), Jaegera (1936) oraz geograficzne Grünthala (1934) i Posera (1939) ${ }^{10}$.

Warto też odnotować, że już w 1884 r. oraz dziesięć lat później zorganizowano w Grazu dwie ważne konferencje poświęcone zagadnieniom promocji turystyki. W 1914 r. powstała w Düsseldorfie Szkoła Hotelarska (Internationales Institut für das Hotelbildungswesen), przekształcona w 1920 r. w wyższą szkołę zawodową (Hochschule für Hotel- und Verkehrswesen), która została zamknięta rok później z powodu kryzysu ekonomicznego (Geschichte der Tourismusforschung, 2020; Kozak, Kozak, 2016). W tym okresie na szczególną uwagę zasługuje działalność Glücksmanna (1929), który w 1929 r. założył w berlińskiej Wyższej
Szkole Handlowej Instytut Badań nad Turystyką (Forschungsinstitut für den Fremdenverkehr der Handelshochschule Berlin) ${ }^{11}$ i rozpoczął wydawanie prawdopodobnie pierwszego w skali światowej czasopisma naukowego poświęconego turystyce, zatytułowanego "Archiv für den Fremdenverkehr" (Haedrich, Kaspar, Klemm, Kreilkamp, 1998; Spode, 2009). Warto też zauważyć, że już w 1934 r. na Wiedeńskim Uniwersytecie Ekonomicznym powstał Instytut Badań nad Turystyką (Institut für Fremdenverkehrsforschung der Wirtschaftsuniversität Wien). Symbolicznie ten pierwszy okres właściwych studiów nad turystyką w obrębie języka niemieckiego można zamknąć osiągnięciami instytucjonalnymi ${ }^{12}$ i naukowymi szkoły szwajcarskiej (Bernecker, Kaspar, Mazanec, 1984; Kozak, Kozak, 2016; Spode, 2009), a zwłaszcza pracami Hunzikera i Krapfa $(1941,1942)$, których dorobek teoretyczny do dzisiaj jest punktem wyjścia do wielu analiz terminologicznych dotyczących tej dziedziny.

Podsumowując charakterystykę spuścizny studiów nad turystyką w obszarze niemieckojęzycznym w okresie do wybuchu II wojny światowej, należy podkreślić, że dla wielu badaczy stanowiła ona już główny obszar zainteresowań naukowych (stąd zakwalifikowanie ich dorobku do okresu studiów właściwych). Badania te podejmowano jednak raczej $\mathrm{w}$ ujęciu jednodyscyplinarnym (głównie ekonomicznym). Przy czym wyjątek może stanowić tutaj działalność obu Instytutów Badań nad Turystyką w Berlinie (Spode, 2009) i Wiedniu, która nosiła znamiona podejścia interdyscyplinarnego. W tym samym kontekście należy odnotować sformułowaną w latach 40. nowatorską propozycję Hunzikera dotyczącą uznania turystyki za oddzielną dziedzinę wiedzy. Gdy z perspektywy XXI w. spojrzy się na dorobek szkoły niemieckojęzycznej (rozwijającej się w Szwajcarii, Niemczech i Austrii), dość wyraźnie widać, że była ona dominująca aż do lat $60 . \mathrm{XX} \mathrm{w} \cdot{ }^{13} \mathrm{~W}$ dekadzie tej wspomniana szkoła zaczęła bowiem tracić na znaczeniu na rzecz działalności badaczy brytyjskich i amerykańskich, którzy przejawiali coraz większe zainteresowanie problematyką turystyczną.

Co się tyczy studiów nad turystyką prowadzonych w pierwszych dekadach XX w. przez badaczy francuskich, to wydaje się, że przejście od etapu prekursorskiego do badań właściwych nastąpiło $\mathrm{w}$ tym przypadku po zakończeniu I wojny światowej ${ }^{14}$. Z tego okresu należy wymienić przede wszystkim takie opracowania, jak: studium urbanistyczno-turystyczne Auschera i Rozeta (1920), prace Blancharda (1919), w tym geograficzno-turystyczną monografię regionu Izery i Grenoble (1925), czy też studium ekonomiczno-turystyczne Gide'a (1928, za: Hsu, Gartner, 2012). Wzrost zainteresowania badaniami nad turystyką był także w dużym stopniu związany z sukcesem zorganizowanej w Grenoble międzynarodowej wystawy „Białego węgla i turystyki" (Exposition internationale de la houille 
blanche et du tourisme), która zwróciła uwagę władz publicznych oraz sfer gospodarczych na znaczenie turystyki dla rozwoju lokalnego i regionalnego (Jackowski, Bilska-Wodecka, Sołjan, Liro, 2015). W wyniku tego zaczęły we Francji pojawiać się coraz liczniejsze opracowania (na początku głównie z inicjatywy geografów), w których podejmowana była tematyka turystyczna (Borrel, 1933; Chaix, 1932; Miège, 1933). Warto przy tym zauważyć, że poza Grenoble, innymi ośrodkami, gdzie prowadzono studia nad turystyka, były uniwersytety w Tuluzie, Bordeaux i Pau (Jackowski, Bilska-Wodecka, Sołjan, Liro, 2015).

Opinię o kluczowej roli badaczy z krajów niemieckojęzycznych (głównie ekonomistów) i francuskojęzycznych (przede wszystkim geografów) na początku okresu studiów właściwych nad turystyką zdają się potwierdzać, w stosunku do genezy badań społecznych nad tą dziedzina, także autorzy pracy zbiorowej pt. The sociology of tourism. European origins and developments, powstałej pod redakcją Danna i Liebman Parrinello (2009), a także - zwłaszcza w odniesieniu do dorobku niemieckiego - tacy badacze, jak: Cohen (1984), Homberg (1978) i Spode (2009). Wyniki analiz sporządzonych przez tych naukowców wskazuja, że początki właściwych badań nad turystyką prowadzonych z szeroko rozumianej perspektywy socjologicznej, a co za tym idzie - w ujęciu jednodyscyplinarnym - w obrębie nauk społecznych, przypadają na lata 30. ubiegłego wieku. Są również związane głównie z obszarem języka niemieckiego (Glücksmann, 1935; Knebel, 1960; Wiese, 1930) oraz od lat 50. także francuskiego z jego bogatą spuścizną teoretyczną w zakresie badań społecznych ${ }^{15}$. Warto jednocześnie zauważyć, że w początkowym okresie studiów socjologicznych i antropologicznych nad problematyką wypoczynku (zwłaszcza we Francji, Niderlandach, Belgii, a nawet w USA) ważne były kwestie czasu wolnego i rekreacji (Dumazedier, 1962; Hourdin, 1962). W opisywanych badanich posługiwano się właściwą tym zagadnieniom aparaturą pojęciową i terminologia (fr. temps libre, loisir, ang. free-time, leisure, frivolity, superfluity), które sięgały swoimi korzeniami jeszcze do XIX-wiecznych teorii społecznych Marksa i Engelsa, a także Webera, czy też do zasad etyki protestanckiej, wskazujących na dychotomię: czas pracy versus czas wolny (Dann, Liebman Parrinello, 2009). Podobne tendencje, ale wynikające już z czysto ideologicznych pobudek, utrzymywały się po 1945 r. w ZSRR i krajach bloku komunistycznego. Biorąc to pod uwagę, należy zauważyć, że w niektórych krajach - w obrębie badań społecznych - studia właściwe nad turystyką w ścisłym znaczeniu miały charakter wtórny (chronologicznie późniejszy) w stosunku do badań nad czasem wolnym. Wydaje się też, że dopiero od lat 60.-70. ubiegłego stulecia studia tego typu zaczęły wypierać socjologiczną refleksję nad czasem wolnym i wypoczynkiem, stając się głównym przedmiotem zainteresowania badaczy społecznych (Lanfant, 1972). Z poglądami tymi w zasadzie zgadza się też Podemski (2005), zauważając, że zjawisko podróżowania o charakterze turystycznym zostało dostrzeżone na szerszą skalę przez socjologów na przełomie lat 50. i 60. ubiegłego wieku. Przy czym warte podkreślenia jest, że wzrost zainteresowania naukowego turystyką sensu stricto zbiegł się w czasie z dynamicznym rozwojem studiów nad tą dziedziną w krajach anglosaskich (głównie w Wielkiej Brytanii i USA, a później także w Australii i Nowej Zelandii) oraz z początkiem trwającej do dziś dominacji tego języka w literaturze przedmiotu i w całej nauce. Wydaje się też, że w krajach tych mniej więcej od lat 70. w badaniach turystycznych można było zaobserwować stopniową zmianę podejścia - z jednodyscyplinarnego na interdyscyplinarne - co stanowiło ważny przełom metodologiczny w studiach nad tą dziedziną (por. Dann, Liebman Parrinello, 2009).

Wracając jednak do genezy studiów nad turystyką w pozostałych krajach europejskich do wybuchu II wojny światowej, można stwierdzić, że tego typu badania były prowadzone raczej sporadycznie i na niewielką skalę. Przy czym ich początki przypadają dopiero na lata 30. XX w. (poza nielicznymi wyjątkami) i dotyczą raczej niewielkiej grupy państw, wśród których na pierwszym miejscu należy wymienić Włochy. Kraj ten ma bowiem długą tradycję, zwłaszcza ekonomicznych badań nad turystyką (Savelli, 2009), i bogaty dorobek w tym zakresie, obejmujący m.in. (za: Hsu, Gartner, 2012) prace Belottiego (1919), Nicefora (1923), Beniniego (1926), Marriottiego ${ }^{16}(1923,1931,1933)$, Tabacchiego (1934) czy Troisiego (1940). Stanowią one jedne z ważniejszych opracowań z tego okresu powstałych poza obszarem języka niemieckiego i francuskiego.

Na tym tle stosunkowo skromnie prezentują się historyczne osiągnięcia (przodującej obecnie) szkoły brytyjskiej, w której obrębie na uwagę zasługują przede wszystkim makroekonomiczne prace Ogilvie'a ${ }^{17}$ (1933) i Norvala (1936). Wcześniej pojawiły się tam też publikacje historyczne dotyczące podróży po kontynencie europejskim (Bates, 1911), ze szczególnym uwzględnieniem tzw. Grand Tour ${ }^{18}$ (Mead, 1914), czy też znacznie późniejsze retrospektywne studium na temat rozwoju nadmorskich miejscowości uzdrowiskowych (Gilbert, 1939). Nie zmienia to jednak faktu, że badacze brytyjscy prowadzili na szerszą skalę badania dotyczące turystyki znaczenie później. Zaś Kozak i Kozak (2016) twierdzą wręcz, że miało to miejsce dopiero na początku lat 70. ubiegłego stulecia i było związane z transformacją gospodarki Wielkiej Brytanii z wytwórczej na usługową. Opinię taką potwierdza także Vukonić (2012) w swoim studium poświęconym rozwojowi teorii turystycznej.

Poza wymienionymi państwami studia nad turystyką w Europie (w okresie do 1939 r.) były też sporadycznie podejmowane $\mathrm{w}$ krajach skandynawskich oraz Belgii i Niderlandach (Ramarker, 1951), a prawdopodobnie 
także $\mathrm{w}$ innych, choć raczej na nieporównywalnie mniejszą skalę. W zasadzie wymienione prace należałoby już zaliczyć do studiów właściwych nad turystyką (prowadzonych jednak z perspektywy jednej dyscypliny - głównie geografii, ekonomii lub socjologii), traktowaną przez wielu badaczy jako główny obszar ich zainteresowań, być może poza pracami stricte historycznymi (Towner, Wall, 1991).

Co się tyczy zainteresowania studiami nad turystyką poza Europa, to wydaje się, że na pierwszym miejscu należy tutaj wskazać Stany Zjednoczone Ameryki Północnej. Chociaż, co warte podkreślenia, skala i znaczenie podejmowanych tam badań w okresie do końca lat 30. ubiegłego stulecia była nieporównywalnie mniejsza niż na Starym Kontynencie. W pierwszych dekadach XX w. w USA ukazywały się bowiem raczej sporadyczne publikacje, $\mathrm{w}$ których poruszano tę problematykę. Zaliczyć do nich należy m.in. prace ekonomiczne (lub geograficzno-ekonomiczne) Browna (1935), Carlsona (1938) i Jonesa (1933), czy też opracowania planistyczno-geograficzne (Joerg, 1935; McMurry, 1930; Meinecke, 1929). Większość z tych publikacji miała bardzo aplikacyjny charakter, co zresztą dobrze wpisywało się $\mathrm{w}$ pragmatyczny wymiar aktywności naukowej w USA. Świadczy o tym także fakt, że już w latach 20. XX w. na Uniwersytecie Cornell (1922), a także w College of Business Uniwersytetu Stanowego Michigan (1927) rozpoczęły działalność szkoły przygotowujące kadry turystyczne (Kozak, Kozak, 2016). Kowalczyk (2001) wskazuje, że w latach 30. ubiegłego stulecia badania nad turystyka, przynajmniej w wymiarze geograficznym, były prowadzone także w Japonii ${ }^{19}$.

\section{GENEZA STUDIÓW NAD TURYSTYKĄ: PRZYKŁAD POLSKI}

Głównym powodem zamieszczenia w niniejszym artykule oddzielnej części poświęconej dorobkowi naukowemu i organizacyjnemu polskich badaczy w zakresie badań nad turystyką ( $w$ ich pierwszym okresie) była chęć pokazania kraju, w którym uczeni, znajdujący się w określonej sytuacji politycznej, społecznej i kulturowej, potrafili wypracować pewien model studiów nad tą dziedziną. Osiągnięcia Polaków w tym zakresie są dość dobrze opisane (przynajmniej w polskiej literaturze), stąd nie ma potrzeby ich szczegółowego przytaczania w tym miejscu. Warto natomiast zwrócić uwagę na specyfikę omawianego modelu, zwłaszcza w okresie prekursorskim. Nie ulega wątpliwości, że wynikała ona z wyjątkowej sytuacji politycznej kraju (brak państwowości do 1918 r.), co miało wpływ na kierunek podejmowanych w tym okresie badań, a w konsekwencji także na zainteresowania i ewolucję naukową badaczy w fazie studiów właściwych. Trzeba też podkreślić, że Polacy podejmujący w tym czasie problematykę turystyczną obficie czerpali z dorobku uczonych niemieckojęzycznych (zwłaszcza w obrębie zaboru austriackiego), a także - choć w mniejszym stopniu - z osiągnięć szkoły francuskiej. Mając to na uwadze, można pokusić się o sformułowanie hipotezy, zakładającej że specyficzny, ze względu na uwarunkowania zewnętrzne, model polski nie miał charakteru zamkniętego, a związane $z$ jego przyjęciem osiągnięcia twórczo uzupełniały dorobek europejski. To, co jednak jest najważniejsze w kontekście celów artykułu, dotyczy postulatu konieczności badania innych „modelów narodowych" studiów nad turystyką i publikacji ich wyników na arenie międzynarodowej ${ }^{20}$. Umożliwi to ciągłe uzupełnianie naszej wiedzy dotyczącej genezy refleksji naukowej nad tą dziedziną w poszczególnych krajach, których dorobek składa się również na obraz całości.

Wracając jednak do modelu polskiego, można stwierdzić, że na tle zarysowanego wcześniej dorobku początkowej fazy studiów nad turystyką w przodujących pod tym względem krajach, osiągnięcia polskich badaczy z tego okresu należy ocenić stosunkowo wysoko zarówno pod względem działalności naukowej, jak i dydaktycznej. Przy czym na podkreślenie zasługuje fakt, że uzyskały one zinstytucjonalizowaną formę w postaci założonego przez S. Leszczyckiego Studium Turyzmu, działającego w latach 1936-1939 na Uniwersytecie Jagiellońskim w Krakowie. Jednostka ta była jedną z nielicznych w Europie, w których zajmowano się zarówno pracą badawcza, jak i kształceniową w zakresie turystyki. Nie powstała ona jednak na tzw. surowym korzeniu, ponieważ tradycja studiów nad tą dziedziną miała w Polsce już pewną tradycję sięgającą czasów zaborów. Przy czym wydaje się, że to właśnie uwarunkowania polityczne i brak państwowości spowodowały, że w okresie prekursorskim (trwającym umownie do 1914 r.) badania te miały swoją specyfikę łączącą się głównie z odkrywaniem związków między ziemią ojczystą a zakorzenioną w niej kultura, tradycjami i religią. $W$ tym sensie badania te można by zaliczyć do studiów o charakterze etnograficzno-chorograficznym, zbliżonych do współczesnego krajoznawstwa, a w szerszej skali - do humanistyczno-regionalnych koncepcji Vidala de la Blache'a. Z omawianego okresu należy podać kilka nazwisk najważniejszych uczonych, przede wszystkim trzeba wymienić: S. Staszica (17551826) - nazywanego niekiedy ojcem polskiego krajoznawstwa ${ }^{21}$; podróżnika i poetę J.U. Niemcewicza (1758-1841)22; geografa W. Pola (1807-1872), stosującego w swoich badaniach podejście Humboldta i Rittera; etnografów i folklorystów O. Kolberga ${ }^{23}$ (1814-1890) i Z. Glogera ${ }^{24}$ (1845-1910); również lekarza i przyrodnika, nazywanego "odkrywcą" Zakopanego - T. Chałubińskiego (1820-1889); a z nieco późniejszego czasu gen. M. Zaruskiego (1867-1941) - żeglarza, taternika i poetę, 
współtwórcę Tatrzańskiego Ochotniczego Pogotowia Ratunkowego; A. Janowskiego ${ }^{25}$ - współzałożyciela Polskiego Towarzystwa Krajoznawczego; wybitnego krajoznawcę i autora przewodników M. Orłowicza (1881-1959); a nawet kompozytora, taternika i publicystę M. Karłowicza (1876-1910). Warto w tym miejscu wyliczyć także kilka stowarzyszeń, które pomagały w poznawaniu ojczystej ziemi m.in. poprzez organizację wycieczek i podróży. Są to: Towarzystwo Filomatyczne i Zgromadzenie Filaretów (1820-1823) ${ }^{26}$, Towarzystwo Tatrzańskie (utworzone w 1873 r.), Warszawskie Towarzystwo Wioślarskie (1878), Warszawskie Towarzystwo Cyklistów (1884), Polskie Towarzystwo Krajoznawcze (1906), Akademicki Klub Turystyczny (1906), Karpackie Towarzystwo Narciarzy (1907), czy też mniej znane, założone nieco później Podolskie Towarzystwo Krajoznawcze (1925) i Wołyńskie Towarzystwo Krajoznawcze (1927).

Jak można zauważyć, przedstawione postacie oraz działacze wymienionych organizacji reprezentowali różne dziedziny życia społecznego, z których tylko część związana była bezpośrednio z nauką. Niemniej dorobek tych osób stanowił dobrą podstawę do rozpoczęcia regularnych studiów nad turystyką w okresie międzywojennym, $\mathrm{z}$ ich apogeum przypadającym na drugą połowę lat 30., kiedy to w 1936 r. rozpoczęło swoją działalność Studium Turyzmu, funkcjonujące do wybuchu II wojny światowej. Historia działalności dydaktycznej i naukowej tej jednostki została dobrze udokumentowana w pracach wielu autorów, w tym przede wszystkim Jackowskiego (wraz z zespołem) (1992, 2011, 2016), a także Leszczyckiego (1992), Tokarskiego (1992) i Wyrzykowskiego (2014). Krytyczną syntezę tych opracowań stanowi obszerna monografia wieloautorska (Jackowski, Bilska-Wodecka, Sołjan, Liro, 2015), poświęcona Studium, w której autorzy przedstawili jego historię i dorobek, również - co szczególnie wartościowe - na tle podobnych osiągnięć w innych krajach. Pozostaje jedynie wyrazić żal, że główny nurt rozważań porównawczych ograniczono w niej do geografii turyzmu, a spuścizna naukowa innych dyscyplin w zakresie badań nad turystyką została zaledwie zaznaczona. W jakimś sensie lukę tę stara się wypełnić, przynajmniej częściowo, niniejsze opracowanie. Wracając jednak do wspomnianej monografii, pewnym zaskoczeniem może być następująca konstatacja autorów: „W stosunku do państw europejskich i Stanów Zjednoczonych typowa geografia turyzmu zaczęła się rozwijać w Polsce stosunkowo późno, w zasadzie po 1930 r." (Jackowski, Bilska-Wodecka, Sołjan, Liro, 2015, s. 26). Można się zgodzić, że takie twierdzenie jest zasadne w odniesieniu do osiągnięć geografów niemieckich i francuskich. Natomiast w przypadku pozostałych krajów europejskich wydaje się, że polski dorobek prezentuje się zupełnie dobrze zarówno pod względem naukowo-poznawczym, jak i dydaktycznym, przede wszystkim dzięki działalności Studium Turyzmu. Opinię taką zdają się też potwierdzać w innym miejscu tego opracowania jego autorzy (Jackowski, Bilska-Wodecka, Sołjan, Liro, 2015, s. 13), stwierdzając, że:

Bez wątpienia ewenementem w skali międzynarodowej było utworzone w 1936 r. w Uniwersytecie Jagiellońskim Studium Turyzmu, z siedzibą w Instytucie Geograficznym. Odegrało ono istotną rolę w rozwoju polskiej i światowej geografii turyzmu, planowania przestrzennego i regionalnego, szczególnie związanego z turystyką oraz w zakresie przygotowania kadr dla rozwijającego się w Polsce ruchu turystycznego.

\section{PODSUMOWANIE I WNIOSKI}

Wydaje się, że na podstawie zaprezentowanej w niniejszym artykule genezy studiów nad turystyka, można sformułować kilka wniosków natury bardziej ogólnej, również w formie tez. Mogą one stanowić przedmiot krytycznej analizy, a być może także inspirację do dalszych badań dotyczących ewolucji refleksji naukowej nad tą dziedzina, zwłaszcza w obszarach pominiętych w tej publikacji.

1. Biorąc pod uwagę dorobek różnych szkół i tradycji naukowych w zakresie studiów nad turystyka, bezdyskusyjne wydaje się twierdzenie, że związane $\mathrm{z}$ nią badania naukowe zostały zapoczątkowane na szeroką skalę na przełomie XIX i XX w. na kontynencie europejskim, przede wszystkim w Niemczech, Austrii i Szwajcarii oraz we Francji i Włoszech. Było to spowodowane dynamicznym rozwojem ruchu turystycznego na określonych, choć stosunkowo niewielkich obszarach geograficznych należących do tych państw (Alpy, wybrzeże morskie, miasta historyczne). Wywoływał on określone konsekwencje ekonomiczne, przestrzenno-środowiskowe oraz społeczne. Zmiany te zwróciły najpierw uwagę ekonomistów i geografów, a później także socjologów, czyniąc z turystyki nowy przedmiot zainteresowań badawczych w obrębie tych dyscyplin. Trzeba przy tym zauważyć, że badania nad fenomenem turystyki w pierwszym okresie miały raczej charakter wyłącznie aplikacyjny. Wydaje się, że w ten sposób można też tłumaczyć znaczne „opóźnienie” w podjęciu tematyki turystycznej przez badaczy brytyjskich i amerykańskich. Kraje te bowiem przede wszystkim generowały ruch turystyczny, w dużo zaś mniejszym stopniu przyjmowały go, wraz ze wszystkimi tego konsekwencjami gospodarczymi, środowiskowymi czy społecznymi.

2. Do rozwoju badań nad turystyką zapoczątkowanego w obszarze języka niemieckiego i we Francji przyczyniły się także (poza czynnikami realnymi wymienionymi w punkcie 1) solidne podstawy teoretyczno-metodologiczne dyscyplin, w których 
ramach prowadzono pierwsze badania. Na szczególną uwagę zasługuje tutaj dorobek XIX-wiecznej niemieckiej szkoły antropogeografii (anthropogeographie), czy też francuskiej tradycji geograficznych studiów regionalnych prowadzonych z perspektywy humanistycznej (géographie humaine). Równie ważną rolę u zarania refleksji naukowej nad turystyką odegrała bogata spuścizna obu krajów w obrębie szeroko pojmowanej myśli i teorii społecznej. Biorąc pod uwagę zaprezentowane tu twierdzenia, można przyjąć, że w sposób naturalny badacze prowadzący pierwsze studia nad turystyka, pochodzący również spoza Francji i krajów niemieckojęzycznych, czerpali z ich bogatego dorobku.

3. Retrospektywna analiza rozwoju badań nad turystyką przeprowadzona z możliwie szerokiej perspektywy, wychodzącej poza ramy jednego kraju, obszaru językowego, czy też tradycji naukowej, pozwoliła wyróżnić trzy podstawowe fazy, częściowo na siebie zachodzące w sensie czasowym, różniące się jednak pod względem metodologii i organizacji prowadzonych badań. Wspomniane fazy to:

- okres prekursorski - historycznie najwcześniejszy - w którym badacze turystyki, nie dysponując jeszcze żadnym specyficznym instrumentarium metodologicznym (ani tym bardziej podstawami teoretycznymi), dostosowanym do nowego obszaru ich studiów, zmuszeni byli do korzystania z dorobku innych, bardziej zaawansowanych dyscyplin, z których się wywodzili i z którymi się w pełni identyfikowali, również podczas prowadzenia badań nad turystyką. W praktyce oznaczało, to że studia w zakresie turystyki były opracowywane w ramach obowiązujących w tym okresie w poszczególnych dyscyplinach paradygmatów badawczych;

- okres studiów właściwych nad turystyką - charakteryzujący się podejściem jednodyscyplinarnym - stanowi drugi w sensie chronologicznym, ale również pod względem zaawansowania metodologiczno-teoretycznego, etap rozwoju refleksji naukowej nad tą dziedziną. Cechuje się on przyznaniem turystyce rangi specyficznego obszaru badań, eksplorowanego z perspektywy różnych dyscyplin z wykorzystaniem ich dorobku teoretycznego oraz instrumentarium metodologicznego. Przy czym w dużo większym stopniu są one dostosowane do specyfiki przedmiotu badań. W pewnym uproszczeniu można przyjąć, że cechą wyróżniającą ten okres, przypadającą na szczytową fazę jego rozwoju, jest ukształtowanie się specyficznych subdyscyplin, takich jak m.in.: geografia turyzmu, ekonomika turystyki, socjologia turystyki i in. Warto jednak zaznaczyć, że badania zakwalifikowane do tego etapu, mimo ich znacznego metodologicznego rozwoju, wciąż opierały się na paradygmatach obowiązujących w poszczególnych dyscyplinach;
- okres studiów właściwych nad turystyką - charakteryzujący się podejściem interdyscyplinarnym - stanowi najbardziej zaawansowaną pod względem teoretyczno-metodologicznym fazę badań nad tą dziedziną. Przy czym cecha, która go w największym stopniu wyróżnia, jest położenie akcentu na interdyscyplinarną syntezę wyników badań prowadzonych z perspektywy poszczególnych nauk. To właśnie ta synteza stanowi najważniejszą wartość dodaną i decyduje o rozwoju teoretycznym badań. Spowodowała ona jednocześnie swoisty przełom polegający na oderwaniu się badaczy od instytucjonalnych i metodologicznych korzeni dyscyplin, z których się wywodzą. Przy czym, w powyższym kontekście, drugorzędną sprawą wydaje się przyznanie turystyce statusu jedynie specyficznego obszaru badań, czy też uznanie jej za samodzielną dyscyplinę, co zresztą było przedmiotem ożywionych dyskusji w ostatnich trzech dekadach (Butowski, 2011; Leiper, 2000; Tribe, 2000).

4. Gdy porównuje się genezę refleksji naukowej nad turystyką w poszczególnych krajach, widać, że w niektórych z nich studia właściwe nad turystyka rozwinęły się w nawiązaniu do dorobku okresu prekursorskiego. Dotyczy to zwłaszcza kontynentalnej Europy (Niemcy, Austria, Francja, Włochy, Polska). Tam zaś, gdzie okres prekursorski nie zaistniał w takim wymiarze (obszar języka angielskiego, głównie Wielka Brytania i USA), badania nad turystyką zaczęły się rozwijać w większym stopniu na tzw. surowym korzeniu. Nie zmienia to faktu, że badacze zajmujący się turystyką w tych krajach czerpali obficie $\mathrm{z}$ dorobku teoretycznego innych dyscyplin (ekonomii, socjologii, antropologii, geografii; a w późniejszym okresie także nauk o zarządzaniu i marketingu).

5. W efekcie do dziś w obrębie studiów właściwych nad turystyką mamy do czynienia z badaniami zarówno o charakterze jednodyscyplinarnym (lub grupy pokrewnych dyscyplin), jak i międzydyscyplinarnym. Wydaje się jednak, że podejście jednodyscyplinarne częściej spotykane jest w krajach, które przeszły przez okres prekursorski (np. w Polsce), charakteryzujący się silnym przywiązaniem badaczy do ich macierzystych dyscyplin. Z kolei w obszarze języka angielskiego, który obecnie zdominował międzynarodową dyskusję naukową nad turystyka, znacznie częściej spotykane jest podejście międzydyscyplinarne. Można to zaobserwować szczególnie wśród badaczy, którzy uzyskali swoje stopnie naukowe, prowadząc studia nad problematyką stricte turystyczną. 6. Zakładając prawdziwość wniosków sformułowanych we wcześniejszych punktach, można krytycznie odnieść się do znanego i często cytowanego modelu ewolucji turystyki, zaproponowanego przez Jafariego $(1989,2001)$ - w odniesieniu do tzw. platformy wiedzy (knowledge-based platform). Autor ten wyróżnił 
bowiem kilka następujących po sobie faz (nazwanych platformami), charakteryzujących rozwój turystyki w poszczególnych okresach. Jedną z nich była platforma wiedzy, stanowiąca fazę, podczas której głównym zadaniem miało być zrozumienie turystyki jako złożonego fenomenu dzisiejszego świata, przy wykorzystaniu instrumentarium badawczego, jakie daje współczesna nauka. Przy czym została ona umiejscowiona jako czwarta pod względem chronologicznym, z określeniem okresu jej rozwoju przypadającego dopiero na lata 90. ubiegłego stulecia ${ }^{27}$. W świetle ustaleń zawartych w niniejszym artykule wydaje się, że wskazana przez Jafariego ostatnia dekada XX w. - jako ta, w której na pierwszy plan wysunięto konieczność naukowego poznania i zrozumienia fenomenu turystyki - jest okresem zbyt późnym. Można przy tym postawić tezę, że przyczyniło się do tego nader anglocentryczne spojrzenie Jafariego na globalny dorobek studiów nad turystyką, bez należytego uwzględnienia w nim spuścizny kontynentalnej Europy. Tezę taką potwierdza również fakt, że bez względu na to, w jakim okresie umiejscowimy dynamiczny rozwój badań nad turystyka, tj. na lata 60. według Butlera (2015) czy lata 90. zgodnie z założeniami Jafariego $(1989,2001)$ lub Kozaka i Kozaka (2016), to w jakimś stopniu koresponduje on z rozwojem podejścia interdyscyplinarnego (przypadającego mniej więcej na lata 70. i 80.), będącego domeną głównie szkoły anglo-amerykańskiej.

7. Wydaje się, że w celu zrekonstruowania w sposób możliwie pełny genezy studiów nad turystyką konieczne jest uwzględnienie w niej także osiągnięć stanowiących dorobek krajów spoza głównych szkół i tradycji naukowych, czy też stref językowych, takich jak: Niemcy, Austria, Szwajcaria, Francja; a w późniejszym okresie także Wielka Brytania, USA, Australia i Nowa Zelandia. Osiągnięcia te stanowiły bowiem często wartościowe uzupełnienie dorobku "głównego nurtu", niestety pozostają prawie zupełnie nieznane na arenie międzynarodowej. Dobrym przykładem może być tutaj zaprezentowany w niniejszym artykule przypadek Polski, gdzie już od lat 30. ubiegłego stulecia prowadzono regularne i dobrze zinstytucjonalizowane badania nad turystyka, w których wykorzystywano także osiągnięcia trwającego w tym kraju co najmniej od połowy XIX w. okresu prekursorskiego. Można przypuszczać, że podobne sytuacje mogły się zdarzać także w innych państwach europejskich, charakteryzujących się często odmiennymi uwarunkowaniami historycznymi, politycznymi, społecznymi, gospodarczymi czy środowiskowymi, które z pewnością miały wpływ na podejmowanie studiów nad szeroko rozumianą turystyką. Wiedza o tych działaniach pozostaje niestety w większości „zamknięta” w obrębie tych krajów (i ich tradycji językowych) i rzadko jest prezentowana na zewnątrz, zwłaszcza w angielskojęzycznej literaturze głównego nurtu. Taki stan rzeczy z pewnością przyczynia się do utrwalania niepełnych, a przez to w jakimś stopniu nietrafnych opinii na temat genezy studiów nad turystyka, zwłaszcza wśród młodszego i średniego pokolenia badaczy anglojęzycznych, czego przynajmniej część z nich jest świadoma (Butler, 2015; Dann, Liebman Parrinello, 2009).

8. Biorąc pod uwagę konkluzję zawartą punkcie 7, można uznać, że należy zachęcać do podejmowania badań nad genezą studiów z zakresu turystyki prowadzonych w różnych krajach, a zwłaszcza do prezentowania ich wyników na arenie międzynarodowej, w językach dostępnych szerokiej publiczności. Dzięki temu możliwe stałoby się uzupełnienie istniejącej luki poznawczej w tym zakresie i lepsze zrozumienie procesu rozwoju refleksji naukowej nad turystyką w skali globalnej, obejmującej przecież osiągnięcia lokalnych szkół i tradycji naukowych. Mimo że taki właśnie był cel tego artykułu, to jego autor ma świadomość, że zakres przeprowadzonej analizy jest daleko niewystarczający (choćby z powodów ograniczeń językowych) i z pewnością należałoby ją poszerzyć o dorobek innych krajów pozostających poza obszarami oddziaływania języków angielskiego, francuskiego, niemieckiego i polskiego, które stanowiły główne źródła informacji niezbędnych do stworzenia tej pracy.

9. Autorowi pozostaje mieć także nadzieję, że to wyzwanie zostanie podjęte, nawet (co równie cenne) w formie polemicznej, być może podważającej w jakimś stopniu ustalenia i tezy przedstawione w niniejszej pracy. Noszą one z pewnością piętno (czasami wręcz zamierzonego) subiektywizmu, którego celem było zwrócenie uwagi społeczności badaczy na niepełna, a przez to wypaczoną wiedzę na temat wkładu małych krajów i ośrodków naukowych w studia dotyczące fenomenu turystyki.

\section{PRZYPISY}

\footnotetext{
${ }^{1}$ Artykuł stanowi część monografii pt. Metodologia badań nad turystyka. Podstawy ontologiczne i epistemologiczne oraz rozwój historyczno-instytucjonalny, złożonej przez autora do druku w Polskim Wydawnictwie Ekonomicznym.

${ }^{2}$ Ich osiągnięcia na poszczególnych etapach rozwoju badań były często zapisywane w specjalnych wydawnictwach, jak np. Podstawy geografii turyzmu (Warszyńska, Jackowski, 1978), Fondements pour une géographie du tourisme et des loisirs (Cazes, 1992), The sociology of tourism: Theoretical and empirical investigations (Apostolopoulos, Leivadi, Yiannakis, 1996), Geografia turyzmu (Kowalczyk, 2001), Socjologia podróży (Podemski, 2005), Geographie der Freizeit und des Tourismus (Becker, Hopfinger, Steinecke, 2007), The study of tourism: Anthropological and sociological beginnings (Nash, 2006), Ekonomika turystyki (Panasiuk, 2008), The study of tourism - foundations from psychology (Pearce, 2011), The discovery of tourism
} 
economics (Dwyer, 2011), Geography of tourism (Mason, 2017), Géographie du tourisme et des loisirs (Duhamel, 2018).

${ }^{3}$ Należy jednak pamiętać, że zaliczanie studiów postdyscyplinarnych do badań interdyscyplinarnych zawiera w sobie błąd logiczny polegający na tym, że interdyscyplinarność zakłada sama w sobie istnienie dyscyplin, postdyscyplinarność zaś - ich odrzucenie (Szczepański, 2013).

${ }^{4}$ Rozwój badań nad turystyką $\mathrm{w}$ aspekcie metodologicznym w latach 1945-2000, zwłaszcza w odniesieniu do aktywności turystycznej, został przedstawiony $\mathrm{w}$ literaturze polskiej m.in. przez Alejziaka (2018).

${ }^{5}$ Stwierdzenie to wydaje się słuszne przede wszystkim w stosunku do badaczy francuskich i polskich. W krajach niemieckojęzycznych palmę pierwszeństwa w tym zakresie dzierżyli ekonomiści.

${ }^{6}$ Termin ten przyjął się także w języku angielskim jako tourism industry lub hospitality industries. W języku polskim funkcjonuje on jako kalka językowa w formie przemyst turystyczny, wypierając inne, bardziej odpowiadające oryginałowi określenie gospodarka turystyczna.

${ }^{7}$ Kozak i Kozak (2016) twierdza, że w początkowym okresie studiów właściwych nad turystyką przodują badania ekonomiczne, co było związane z potrzebami gospodarczymi krajów odbudowujących się po I wojnie światowej.

${ }^{8}$ W 1902 r. prowadził w Monachium wykład zatytułowany Wptyw turystyki na rozwój Bawarii (Spode, 2009).

${ }^{9}$ Traktującego turystykę (niem. oryg. Fremdenverkehr) bardzo szeroko - jako sumę wszystkich działań gospodarczych związanych z podróżami.

${ }_{10}$ Poza przywołanymi autorami Vukonić (2012) wymienia także inne nazwiska badaczy niemieckojęzycznych, którzy podejmowali $\mathrm{w}$ tym okresie problematykę turystyczna, w tym:. F. Bartscha, P. Mechtera z Austrii, a także L. Woerla, F.M. Buschela, G. Ströhmefelda, O. Kampa, K. Köhnego, M. Kraussa, F. Oppenheimera, M. Klafkowskiego. K. Thiessa, R. Bodo, K. Brennera, D. Tremohlena, E. Dietla, W. Mahleberga, E. Suttera, A. Rockstroha czy F. Drosihna z Niemiec.

${ }^{11}$ Instytut istniał do 1935 r. (niektóre źródła podaja, że do 1934 r.), kiedy to został zamknięty z powodu kryzysu ekonomicznego. Przy czym znaczenie miał również fakt, że jego założyciel R. Glücksmann był pochodzenia żydowskiego (Spode, 2009).

12 W 1941 r. powstał m.in. w Bernie Forschungsinstitut für Fremdenverkehr (Instytut Badań Turystycznych).

${ }^{13}$ Wiele ważnych teoretycznych studiów nad turystyka, których autorami byli badacze niemieckojęzyczni, powstało w latach 50. Zaliczyć do nich należy m.in. makro-i mikroekonomiczne prace Thomsa (1952), Krapfa (1953), Joschkego (1953), Berneckera (1956), Walterspiela (1956a, 1956b, 1956c) czy Hunzikera (1959).

${ }^{14}$ Aczkolwiek wiele prac Blancharda $(1911,1914)$ z wcześniejszego okresu można by zakwalifikować do studiów właściwych nad turystyką.

${ }^{15}$ Warto jednocześnie zauważyć, że za prekursorów badań społecznych w obrębie szeroko rozumianego czasu wolnego i turystyki można by w jakimś sensie uznać także Veblena (1899) z jego słynną pracą pt. Teoria klasy próżniaczej (ang. The theory of the leisure class) oraz Lévi-Straussa (1955) z nie mniej znanym dziełem Smutek tropików (fr. Tristes tropiques), a także Simmla (1908) z zarysowaną przez niego sylwetką ",obcego" (niem. der Fremde). Paradoksalnie dwa pierwsze teksty były ujęciami, w których autorzy bardzo krytycznie odnieśli się do aktywności związanej z czasem wolnym (Veblen) i podróżami (Lévi-Strauss). Dla żadnego z trzech wymienionych badaczy turystyka (rekreacja, podróże) nie stanowiła też głównego przedmiotu zainteresowań naukowych, a służyła raczej do opisu społeczeństwa z określonych perspektyw badawczych. Natomiast prace tych uczonych stanowiły niewątpliwie inspirację dla badaczy podejmujących tematykę turystyczną sensu stricto.
${ }^{16}$ Już od 1925 r. prowadził on na Uniwersytecie w Rzymie wykłady poświęcone ekonomicznym aspektom turystyki (Medlik, 1965).

${ }^{17}$ Dotyczyły one m.in. ekonomicznych aspektów turystyki jako niewidzialnego eksportu. Według Vukonicia (2012) inspiracją dla Ogilvie'a była w tym zakresie praca Muna (1664).

${ }^{18}$ Jedną z pierwszych prac na temat Grand Tour były Dialogues on the use of foreign travel. Considered as a part of an English gentleman's education, between Lord Shaftesbury and Mr. Locke autorstwa Hurda (1764).

${ }^{19}$ Autor nie podaje jednak bliższych danych źródłowych.

${ }^{20}$ Niestety w zdecydowanej większości publikacji angielskojęzycznych dorobek krajów spoza tzw. głównego nurtu jest prawie zupełnie nieuwzględniany (por. Kozak, Kozak, 2016). Wynika to prawdopodobnie z niedostatecznej wiedzy ich autorów, przynajmniej w zakresie rozwoju studiów nad turystyką w takich krajach, jak np.: Polska, była Jugosławia, czy też dawna Czechosłowacja. Chlubnym wyjątkiem może być tutaj praca zbiorowa pod redakcją Danna i Liebman Parrinello (2009), do której napisania zostali zaproszeni autorzy z wielu krajów.

${ }^{21}$ Autora m.in. pracy pt. O ziemiorództwie Karpatów i innych gór i równin Polski (Staszic, 1815).

${ }^{22}$ Autora m.in. wydanych wiele lat po jego śmierci Podróży historycznych po ziemiach polskich między rokiem 1811 a 1828 rokiem odbytych (Niemcewicz, 1858).

${ }^{23}$ Autora monumentalnego dzieła pt. Lud. Jego zwyczaje, sposób życia, mowa, podania, przysłowia, obrzędy, gusła, zabawy, pieśni, muzyka i tańce, wydawanego od 1857 r. (zob. Kolberg, 1857-1890) Do śmierci autora opublikowano 33 tomy, w tym 10 sygnowanych jako Obrazy etnograficzne.

${ }^{24}$ Głównego autora m.in. Encyklopedii staropolskiej ilustrowanej, wydanej w czterech tomach w latach 1900-1903 (zob. Gloger, 1900-1903).

${ }^{25}$ Autora m.in. Wycieczek po kraju - czterotomowego dzieła wydanego w latach 1900-1903 (Janowski, 1900-1903).

${ }^{26}$ Zwrot ku podróżom i poznaniu swojego kraju lub obcych krain był cechą charakterystyczną dla epoki romantyzmu w całej Europie. Takie wyprawy uzyskały nawet miano les voyages touristiques, a wśród najsłynniejszych podróżników z tego okresu Vukonić (2012) wymienia J.W. Goethego, F.R. Chateaubrianda, Ch. Nodiera, Stendhala, G.G. Byrona, G. Sand, H. Heinego, A. Dumasa czy A. de Musseta, zapominając niestety chociażby o F. Chopinie czy A. Mickiewiczu.

${ }^{27}$ Odmienną opinię prezentuje w tym zakresie Butler (2015), wskazując na lata 60. ubiegłego stulecia jako na okres, kiedy nastąpił dynamiczny rozwój studiów nad turystyka, przynajmniej w Ameryce Północnej.

\section{BIBLIOGRAFIA}

Alejziak, W. (2018). Research on tourist activity in Europe: Methodological aspects and results (Part I: The period 1945-2000). Folia Turistica, 46, 9-48. DOI: https://doi. org/10.5604/01.3001.0012.0842

Angerer, J. (1881a). Das Fremdenwessen im deutschen Südtirol. Bozen: Comm.-Verl. d. Promperger'schen Buchhldg.

Angerer, J. (1881b). Statistischer Bericht der Handels- und Gewerbekammer en Bozen. Bozen: Promperger in Comm.

Apostolopoulos, Y., Leivadi, S., Yiannakis, A. (1996). The sociology of tourism: Theoretical and empirical investigations. London: Taylor \& Francis Ltd.

Auscher, L. (1904). Le tourisme en automobile. Paris: Éditions Vve Ch. Dunod.

Auscher, L., Rozet, G. (1920). Urbanisme et tourisme. Paris: E. Leroux, Coll, Urbanisme. 
Avancini, M. (1925). Statistica del movimento turistico in Italia. Anno 1924. Roma: Tipografia del Senato.

Bates, E.S. (1911). Touring in 1600: A study in the development of travel as a means of education. London: Constable.

Becker, C., Hopfinger, H., Steinecke, A. (2007). Geographie der Freizeit und des Tourismus. Bilanz und Ausblick. München: Oldenburg Wissenschaftsverlag GmbH. DOI: https://doi. org/10.1524/9783486700015

Belotti, B. (1919). Il diritto turistico nella legge, nella dottrine e nella giurispreudenza. Milano: Touring Club Italiano Milano.

Benini, R. (1926). Sulla riforma dei metodi di calcolo dei movimento turistico. Roma: [b.w.].

Bernecker, P. (1956). Die Stellung des Fremdenverkehrs im Leistungssystem der Wirtschaft. Wien: Österreichischer Gewerbeverl.

Bernecker, P., Kaspar, C., Mazanec, J. (1984). Zur Entwicklung der Fremdenverkehrsforschung und - lehre der letzten Jahre. Vienna: Service-Fachverlag der WU Wien.

Blanchard, R. (1911). Grenoble. Études de géographie urbaine. Paris: A. Colin.

Blanchard, R. (1914). Le tourisme en Corse. Revue Mensuelle du Touring Club de France, 24, 2-7.

Blanchard, R. (1919). Nice et les Alpes maritimes. Esquisse Économique. Les Alpes Économiques, 6, 109-119.

Blanchard, R. (1925). Le tourisme dans l'Isère, Grenoble et sa region. Grenoble: Allier.

Bodio, L. (1899). Sul movimento dei foresteri in Italia e sul dinero chi vi spendono. Giornalle degli Economisti, 15, 54-61.

Bogucki, J., Woźniak, A. (1997). Turystyka. W: Z. Krawczyk (red.), Encyklopedia kultury polskiej XX w. Kultura fizyczna - sport (s. 20). Warszawa: Instytut Kultury.

Bormann, A. (1931). Die Lehre vom Fremdenverkehr. Berlin: Verkehrswissenschaftliche Lehrmittelgesellschaft bei der Deutschen Reichsbahn.

Borrel, A. (1933). Le tourisme en France. Paris: J. Téqui.

Brougier, A. (1902). Die Bedeutung des Fremdenverkehrs für Bayern. München: Druck von H. Gldenbourg. DOI: https:// doi.org/10.1515/9783486731729

Brown, R.M. (1935). The business of recreation. Geographical Review, 25, 467-475. DOI: https://doi.org/10.2307/209315

Butler, R. (2015). The evolution of tourism and tourism research. Tourism Recreation Research, 40 (1), 16-27. DOI: https://doi.org /10.1080/02508281.2015.1007632

Butowski, L. (2011). Turystyka jako dyscyplina nauki (artykuł dyskusyjny). Turyzm/Tourism, 21 (1-2), 17-24. DOI: https:// doi.org/10.2478/v10106-011-0002-8

Butowski, L., Kaczmarek, J., Kowalczyk-Anioł, J., Szafrańska, E. (2019). Social constructionism as a tool to maintain an advantage in tourism research. Tourism Geographies, DOI: https://doi. org/10.1080/14616688.2019.1654537

Carlson, A.S. (1938). Recreation industry of New Hampshire. Economic Geography, 14, 255-270. DOI: https://doi.org/10.2307/141343

Cazes, G. (1992). Fondements pour une géographie du tourisme et des loisirs. Rosny: Breal.

Chaix, E. (1932). Une industrie nouvelle. Le tourisme. Revue de Deux Mondes, 7 (1), 63-93.

Chambers, D., Buzinde, C. (2015). Tourism and decolonisation: Locating research and self. Annals of Tourism Research, 51, 1-16. DOI: https://doi.org/10.1016/j.annals.2014.12.002

Cohen, E. (1984). The sociology of tourism: Approaches, issues and findings. Annual Review of Sociology, 10, 373-392. DOI: https://doi.org/10.1146/annurev.so.10.080184.002105

Dann, G., Liebman Parrinello, G. (red.) (2009). The sociology of tourism. European origins and developments. Bingley UK: Emerald Group Publishing Limited.
Darbellay, F., Stock, M. (2012). Tourism as complex interdisciplinary research object. Annals of Tourism Research, 39 (1), 441-458. DOI: https://doi.org/10.1016/j.annals.2011.07.002

Duhamel, P. (2018). Géographie du tourisme et des loisirs. Dynamiques, acteurs, territoires. Paris: Armand Colin. DOI: https://doi. org/10.3917/arco.duham.2018.01

Dumazedier, J. (1962). Vers une civilisation du loisir? Paris: Seuil.

Dwyer, L. (red.) (2011). The discovery of tourism economics, tourism social science series. T. 16. Bingley: Emerald.

Echtner, C.M., Jamal, T.B. (1997). The disciplinary dilemma of tourism studies. Annals of Tourism Research, 24, 868-883. DOI: https://doi.org/10.1016/S0160-7383(97)00060-1

Geschichte der Tourismusforschung (2020). Pobrane z: https:// de.wikipedia.org/wiki/Geschichte_der_Tourismusforschung (18.06.2020).

Gilbert, E.W. (1939). The growth of inland and seaside health resorts in England. Scottish Grographical Magazine, 55, 116-135. DOI: https://doi.org/10.1080/00369223908735100

Gloger, Z. (1900-1903). Encyklopedia staropolska ilustrowana. T. 1-4. Warszawa: P. Laskauer i W. Babicki.

Glücksmann, R. (1917). Privatwirtschaftslehre des Hotelgewerbes. Berlin: M. Paschke.

Glücksmann, R. (1929). Das Ziel des Forschungsinstituts für den Fremdenverkehr. Sonderdruck aus der Zeitschrift "verkehr und Bäder". T. 23. Berlin: Bäder - Verkehrs - Verlag G.m.b.H.

Glücksmann, R. (1935). Allgemaine Fremdenverkehrskunde. Berne: Verlag Stämpfli und Cie.

Grünthal, A. (1934). Probleme der Fremdenverkehrsgeografie. Berlin: Dissertation Handels-Hochschule.

Guyer-Freuler, E. (1874). Hotelwesen der Gegenwart. Zurich: Von Orell Füssli \& Co.

Guyer-Freuler, E. (1884). Das Hotelwesen. Zürich: Drück von Orell Füssli.

Guyer-Freuler, E. (1895). Beiträge zur Statistik des Fremdenverkehrs in der Schweiz. Zürich: Orell Füssli.

Guyer-Freuler, E. (1905). Fremdenverkehr und Hotelwesen. Berne (Germany): Verlag Enzyklopädie.

Haedrich, G., Kaspar, C., Klemm, K., Kreilkamp, E. (1998). TourismusManagement und Fremdenverkehrsplanung. Berlin-Nowy Jork: Walter de Gruyter. DOI: https://doi.org/10.1515/9783110815993

Hall, C.M. (2004), Reflexivity and tourism research. W: J. Phillimore, L. Godson (red.), Qualitative research in tourism (s. 137155). Londyn: Routledge.

Hassert, K. (1908). Die Städte geographisch betrachtet. Lipsk: B.G. Teubner. DOI: https://doi.org/10.2307/198514

Hettner, A. (1927). Die Geographie, ihre Geschichte, ihr Wesen und ihre Methoden. Wroclaw: Ferdinand Hirt.

Homberg, E. (1978). Reisen-zwischen Kritik und Analyse; zum Stand der Tourismusforschung. Z. Kult, 28 (3), 4-10.

Hourdin, G. (1962). Une civilisation des loisirs. Paryż: Calmann-Lévy.

Hsu, C.H.C., Gartner, W.C. (2012). The Routledge handbook of tourism research. Londyn: Routledge. DOI: https://doi. org/10.4324/9780203123287

Hunziker, W. (1959). Betriebswirtschaftslehre des Fremdenverkehrs: Der Fremdenverkehrsbetrieb und seine Organisation. Berno: Gurtenverlag.

Hunziker, W., Krapf, K. (1941). Beiträge zur Fremdenverkehrslehre und Fremdenverkehrsgeschichte. Berno: Publikationen des schweizerischen Fremdenverkehrsverbandes.

Hunziker, W., Krapf, K. (1942). Grundriss der allgemeinen Fremdenverkehrslehre. Zurych: Polygraphischer Verlag.

Hurd, R. (1764). Dialogues on the use of foreign travel. Considered as a part of an English gentleman's education, between lord shaftesbury and $m r$. Locke. Londyn (the Strand): A. Millar; Cambridge: W. Thurlbourn and J. Woodyer. 
Jackowski, A. (1992). Studium Turyzmu Uniwersytetu Jagiellońskiego (1936-1939). Zarys działalności dydaktycznej i naukowej. Zeszyty Naukowe UJ. Prace Geograficzne, 89, 39-59.

Jackowski, A., Bilska-Wodecka, E., Sołjan, I., Liro, J. (2015). Studium Turyzmu Uniwersytetu Jagiellońskiego (1936-1939) i jego rola w rozwoju geografii turyzmu. Kraków: Instytut Geografii i Gospodarki Przestrzennej Uniwersytetu Jagiellońskiego w Krakowie.

Jackowski, A., Sołjan, I. (2011). Próba nowego spojrzenia na początki geografii turyzmu w Polsce (do roku 1939). W: B. Włodarczyk (red.), Turystyka. Księga jubileuszowa w 70. rocznice urodzin Profesora Stanistawa Liszewskiego (s. 33-51). Łódź: Wydawnictwo Uniwersytetu Łódzkiego.

Jackowski, A., Sołjan, I., Bilska-Wodecka, E., Liro, J. (2016). Geographical tourism research and education at the Jagiellonian University School of Tourism in Poland (1936-1939). History of Geo- and Space Sciences, 7, 91-101. DOI: https://doi. org/10.5194/hgss-7-91-2016

Jaeger, F. (1936). Werbung im Fremdenverkehr. Eine wissenschaftliche Untersuchung unter besonderer Berücksichtigung der Tiroler Verhältnisse. Innsbruck: Gemeinschaftsverl. der Sozialwiss. Arbeitsgemeinschaft.

Jafari, J. (1989). Structure of tourism. W: S.F. Witt, L. Moutinho (red.), Tourism marketing and management handbook (s. 437-442). Londyn: Prentice Hall.

Jafari, J. (1990). Research and scholarship: The basis of tourism education. Journal of Tourism Studies, 1, 33-41.

Jafari, J. (2001). The scientification of tourism. W: V.L. Smith, M.A. Brent (red.), Hosts and guests revisited: Tourism issues in the $21^{\text {st }}$ century (s. 28-41). Nowy Jork: Cognizant Communication Corporation.

Jafari, J., Xiao, H. (red.) (2016). Encyclopedia of tourism. [b.m.]: Springer Reference. DOI: https://doi.org/10.1007/978-3-319-01384-8

Janowski, A. (1900-1903). Wycieczki po kraju. Warszawa: wydane nakładem autora.

Joerg, W.L.G. (1935). Geography and national land planning. Geographical Review, 25, 177-208. DOI: https://doi. org/10.2307/209596

Jones, S.B. (1933). Mining and tourist towns in the Canadian Rockies. Economic Geography, 9, 368-378. DOI: https://doi. org/10.2307/140491

Joschke, H. (1953). Beitrag zur theoretischen analyse des fremdenverkehrsangebote. Jahrbuch für Fremdenverkehr, 2 (1).

Just, R. (1907). Die Gemeinde Arose, ihr Wirtschaftsleben vor und seit dem Fremdenverkehr. Zurych: J. Leemann.

Knebel, H.J. (1960). Soziologische Strukturwandlungen im Modernen Tourismus. Stuttgart: Ferdinand Enke.

Kohl, J.G. (1841). Der Verkehr und die Ansiedelungen der Menschen in ihrer Abhängigkeit von der Gestaltung der Erdoberfläche. Drezno: Arnold.

Kolberg, O. (1857-1890). Lud. Jego zwyczaje, sposób życia, mowa, podania, przysłowia, obrzędy, gusła, zabawy, pieśni, muzyka i tańce. Różni wydawcy.

Kowalczyk, A. (2001). Geografia turyzmu. Warszawa: Wydawnictwo Naukowe PWN.

Kozak, M., Kozak, N. (2016). Institutionalisation of tourism research and education: From the early 1900s to 2000s. Journal of Tourism History, 8 (3), 275-299. DOI: https://doi.org/10.108 0/1755182X.2017.1284274

Krapf, K. (1953). Die touristische Konsum: Ein Beitrag zur Lehre von der Konsumption.

Krieger, W. (1933). Werbtechnik im Fremdenverkehr. Wiedeń: [b.w.].

Lanfant, M.-F. (1972). Les théories du loisir. Sociologie du loisir et idéologies. Paryż: Presses Universitaires de France - PUF.

Lasserre, P. (1930). Lourdes. Étude géographique. Revue géographique des Pyrénées et du Sud-Ouest, 1, 5-40. DOI: https://doi. org/10.3406/rgpso.1930.3942
Leiper, N. (1990). Tourism systems: An interdiscyplinary study. Occasion Papers, 2. Palmerston: Massey University.

Leiper, N. (2000). An emerging discipline. Annals of Tourism Research, 27, 805-809. DOI: https://doi.org/10.1016/S0160-7383(99)00118-8 Leszczycki, S. (1992). Geneza i powstanie Studium Turyzmu na Uniwersytecie Jagiellońskim w Krakowie. Zeszyty Naukowe UJ. Prace Geograficzne, 89, 9-37.

Lévi-Strauss, C. (1955). Tristes tropiques. Paryż: Plon.

Marriotti, A. (1923). L'industria del forestiero in Italia: Economica e politica del turismo. Bolonia: Zanichelli.

Marriotti, A. (1931). L'importanza economica del turismo. Florencja: Edizioni AESTI.

Marriotti, A. (1933). Corso di economia turistica. Rzym: Instituto Geografico de Agostini.

Mason, P. (2017). Geography of tourism. Oksford UK: Goodfellow Publishers Limited. DOI: https://doi.org/10.23912/9781911396437-3402

McKercher, B. (2002). The privileges and responsibilities of being a referee. Annals of Tourism Research, 29, 856-859. DOI: https:// doi.org/10.1016/S0160-7383(01)00091-3

McMurry, K.C. (1930). The use of land for recreation. Annals of the Association of American Geographers, 20, 7-20. DOI: https:// doi.org/10.1080/00045603009356913

Mead, W.E. (1914). The grand tour in the eighteenth century. Nowy Jork: Houghton Mifflin.

Medlik, S.R. (1965). Higher education and research in tourism in Western Europe. Londyn: University of Surrey.

Meinecke, E.P. (1929). The effect of excessive tourist travel on California redwood parks. Sacramento: California State Printing Office.

Miège, J. (1933). La vie touristique en Savoie. Revue de Géographie Alpine, 21 (4), 749-817. DOI: https://doi.org/10.3406/ rga.1933.5380

Morgenroth, W. (1927). Fremdenverkehr. Handwörterbuch der Staatswissenschaften, 4.

Mun, T. (1664). England's treasure by forraign trade or the balance of forraign trade is the rule of our treasure. Londyn: Printed by J.G. for Thomas Clark.

Nash, D. (red.) (2006). The study of tourism: Anthropological and sociological beginnings. Bingley: Emerald.

Niceforo, A. (1923). Il movimento dei forestieri in Italia. Rzym: Tipografia del Senato.

Niemcewicz, J.U. (1858). Podróże historyczne po ziemiach polskich między rokiem 1811 a 1828 rokiem odbyte. Paryż: A. Franck; Petersburg: B.M. Wolff.

Norval, A.J. (1936). The tourist industry: A national and international survey. The Economic Journal, 46 (184), 732-734. DOI: https://doi.org/10.2307/2224701

Ogilvie, F.W. (1933). The tourist movement. An economic study. Londyn: P.S. King \& Son.

Panasiuk, A. (2008). Ekonomika turystyki. Warszawa: Wydawnictwo Naukowe PWN.

Pearce, P.L. (2011). The study of tourism: Foundations from psychology. Bingley: Emerald.

Pearce, P.L., Butler, R. (red.). (1993). Tourism research: Critiques and challenges. Londyn: Routledge.

Podemski, K. (2005). Socjologia podróży. Poznań: Wydawnictwo Naukowe UAM.

Poser, H. (1939). Geographische Studien über den Fremdenverkehr im Riesengebirge: ein Beitrag zur geographischen Betrachtung des Fremdenverkehrs. Göttingen: Vandenhoeck \& Ruprecht.

Ramaker, J. (1951). La sociologie du tourisme. Zeitschrift für Fremdenverkehr, 6 (2), 73-76.

Rátz, T. (2014). Crossdisciplinarity or tourismology? The scientific identity of tourism in Hungary. W: L. Butowski (red.), Searching for the scientific identity of tourism research (s. 35-57). Warszawa: Warsaw School of Tourism and Hospitality Management. 
Ratzel, F. (1882). Anthropogeographie Grunzüge oder der Anwendung der Erdkunde auf die Geschichte. Stuttgart: J. Engelhorn.

Savelli, A. (2009). Tourism in Italian sociological thaught and study. W: G. Dann, G. Liebman Parrinello (red.), The sociology of tourism. European origins and developments (s. 131-168). Bingley UK: Emerald Group Publishing Limited.

Schullern-Schrattenhofen, H. von (1911). Frendemverkehr und Volkswirtscahft. Jahrbücher für Nationalökonomie und Statistik Zeitschriftenheft, 4, 433-491. DOI: https://doi.org/10.1515/ jbnst-1911-0130

Simmel, G. (1908). Soziologie. Untersuchungen über die Formen der Vergesellschaftung. Berlin: Duncker \& Humblot.

Smith, M. (1998). Social science in question. Towards a post-disciplinary framework. Londyn: Sage.

Spode, H. (2009). Tourism research and theory in Germanspeaking countries. W: G. Dann, G. Liebman Parrinello (red.), The sociology of tourism. European origins and developments (s. 6594). Bingley UK: Emerald Group Publishing Limited.

Sputz, K. (1919). Die geographischen Bedingungen und Wirkungen des Fremdenverkehrs in Tirol. Praca doktorska. Wiedeń: Uniwersytet w Wiedniu.

Staszic, S. (1815). O ziemiorództwie Karpatów i innych gór i równin Polski. Warszawa: Drukarnia Rządowa.

Stradner, J. (1890). Die Förderung des Fremdenverkehrs. Kulturbildern aus Steiermark, 257-288.

Stradner, J. (1905). Der Fremdenverkehr: Eine folkswirtschaftliche Studie. Graz: Leykam.

Stringer, B. (1912). Sulla bilanza dei pagamenti fra Italia e l'estero. Rzym: Tipografia nazionale di G. Bertero e C.

Szczepański, J. (2013). Dyscyplina nauk o polityce. Status teoretyczny i prawny. Pobrane z: https://www.academia.edu/25428238/ Dyscyplina_nauk_o_polityce_Status_teoretyczny_i_prawny (20.08.2020)

Tabacchi, G. (1934). Turismo ed economia. Aspetti economici del fenomeno turistico. Rzym: ENIT.

Thoms, W. (1952). Die Arten und der Charakter des Fremdenverkehrsbetriebs. W: Handbuch für Fremdenverkehrsbetriebs. Giessen: $\mathrm{Hb}$ Thoms.

Tokarski, Z. (1992). Wydawnictwa Studium Turyzmu Uniwersytetu Jagiellońskiego w Krakowie. Zeszyty Naukowe UJ. Prace Geograficzne, 89, 61-87.

Towner, J., Wall, G. (1991). History and tourism. Annals of Tourism Research, 18, 71-84. DOI: https://doi.org/10.1016/0160-7383(91)90040-I

Tribe, J. (1997). The indiscipline of tourism. Annals of Tourism Research, 24, 638-654. DOI: https://doi.org/10.1016/S0160-7383(97)00020-0

Tribe, J. (2000). Indisciplined and unsubstantiated. Annals of Tourism Research, 27 (3), 809-813. DOI: https://doi.org/10.1016/ s0160-7383(99)00122-X
Tribe, J. (2006). The truth about tourism. Annals of Tourism Research, 33 (2), 360-381. DOI: https://doi.org/10.1016/j. annals.2005.11.001

Tribe, J., Liburd, J.J. (2016). The tourism knowledge system. Annals of Tourism Research, 57, 44-61. DOI: https://doi.org/10.1016/j. annals.2015.11.011

Tribe, J., Xiao, H. (2011). Developments in tourism social science. Annals of Tourism Research, 38 (1), 7-26. DOI: https://doi. org/10.1016/j.annals.2010.11.012

Troisi, M. (1940). Prima line di una teoria della rendita turistica. Padwa: CEDAM.

Veblen, T. (1899). The theory of the leisure class. New York: Mac Millan.

Vidal de la Blache, P. (1922). Principes de géographie humaine. Paris: A. Colin.

Vukonić, B. (2012). An outline of the history of tourism theory. Source material (for future research). W: C.H.C. Hsu, W.C. Gartner (red.), The Routledge handbook of tourism research (s. 3-27). Londyn: Routledge.

Walterspiel, G. (1956a). Grundlagen der Betriebswirtschafts lehre des Fremdenverkehrs. Jahrbuch für Fremdenverkehr. Teil I JfF 4. Jg.: 3-13.

Walterspiel, G. (1956b). Grundlagen der Betriebswirtschafts lehre des Fremdenverkehrs. Jahrbuch für Fremdenverkehr. Teil II JfF 5. Jg.: 3-17.

Walterspiel, G. (1956c). Grundlagen der Betriebswirtschafts lehre des Fremdenverkehrs. Jahrbuch für Fremdenverkehr. Teil III JfF 5. Jg.: 39-46.

Warszyńska, J., Jackowski, A. (1978). Podstawy geografii turyzmu. Warszawa: Państwowe Wydawnictwo Naukowe.

Wiese, J. von. (1930). Fremdenverkehr als zwischenmenschliche Beziehungen. Archiv für den Fremdenverkehr, 1, 1-3.

Wijesinghe, S.N., Mura, P., Bouchon, F. (2017). Tourism knowledge and neocolonialism - a systematic critical review of the literature. Current Issues in Tourism, 22, 1263-1279. DOI: https://doi.org/10.1080/13683500.2017.1402871

Wyrzykowski, J. (2014). Achievements of geographical sciences in Poland in tourism research. W: L. Butowski (red.), Searching for the scientific identity of tourism research (s. 127144). Warszawa: Warsaw School of Tourism and Hospitality Management.

Zollinger, W. (1916). Fremdenverkehr und Zalungsbilanz. Jena: [b.w.]

Artykuł wpłyną: 6 marca $2020 \mathrm{r}$.

Zaakceptowano do druku: 23 października $2020 \mathrm{r}$. 